\title{
Are you thinking about writing a bibliography?
}

\author{
By Mike Haddock
}

\section{Tips for a winning title}

- ibliographies play an exceedingly valuable role in the research process. Theodore Besterman's A World Bibliography of Bibliographies and Alice Toomey's supplement together list more than 135,000 titles, and they cover only through the year 1974! Thousands more have appeared in the twenty years since. The Eunice Rockwood Oberly Memorial Award for Bibliography in Agricultural Sciences was established in 1922 to provide national recognition of bibliographic scholarship in the field of agricultural or related sciences. This award is administered by ACRL's Science and Technology Section and is presented in odd-numbered years at the ALA Annual Conference. ( $E d$. note: Application procedures are on page 507.) Over the years, the Oberly jury has judged many bibliographic submissions, some of extremely high quality, some of lesser prominence. The currently serving Oberly Award Committee members felt it might prove valuable to individuals contemplating the creation of a bibliography (in any field) to offer hints as to what constitutes a bibliography of distinction.

\section{Preliminary considerations}

When considering writing a bibliography, the potential author should first determine whether there is a significant need for such a work. Will it make a unique contribution to the body of knowledge? The compiler of a bibliography should be a specialist in the subject field that is to be covered. ${ }^{1}$ This will provide competent judgment as to what should or should not be

included in the work. It is preferable, though not always possible, for the compiler to personally examine all items to be included in the bibliography. Most importantly, as D. W. Krummel notes, the bibliographer requires adequate time to complete the bibliography. ${ }^{2}$

\section{Introductory material}

One of the first areas where a bibliography can show weakness is in its introductory material, or the lack thereof. The author should consider whether his or her introduction states the objective of the bibliography clearly and concisely. A good introduction should delineate the primary organization of the work and describe the format in which the citations will occur. Additional relevant background information will facilitate the usefulness of the bibliography. Such information can be as varied as abbreviation or stop-word lists or sketches of the author's credentials.

Additional features can greatly enhance prefatory material. Have the scope and content been unambiguously identified? Readers like to know what has been excluded as well as what is actually covered. What is the audience that the bibliography is being created for? Is the audience highly limited? Though this is not necessarily a negative, publishers will be much more receptive if the potential audience is not so narrow as to place great constraints on sales. Has the timeliness of the topic been considered, when appropriate? If in-depth reflection has not been given to the purpose, scope, and intended audience, the project should be seriously reconsidered.

\section{Coverage}

A high-caliber bibliography will provide in- 
depth coverage of its chosen subject. Completeness within the stated scope should be the goal. Many bibliographies are less than successful in this regard. Have all possible resources been exhausted in the compiling of the work? If the bibliography is not intended to be comprehensive, but has been limited by time period, language, geographic area, etc., this should be clearly articulated in the introductory materials. Readers should also be informed of what types of materials have been included, e.g., books, journal articles, conference proceedings, research or technical reports, dissertations, government documents (both state and federal), videotapes, films, manuscripts, etc. The author should also state what types of materials, if any, that have been purposely excluded.

\section{Citations must be accurate}

The most significant features of outstanding bibliographies are their accuracy and citation completeness. All citations should be verified before publication! The Oberly Committee has seen bibliographies with partial citations, misspelled words, nonstandard abbreviations, and conferences cited with no date or location given. Inaccuracies can lead users of the bibliography to view the entire work with a certain amount of skepticism.

The layout of each citation should remain consistent. If citations to differing media appear, these should be identified and described. The time lag between the termination of work on the bibliography and its publication should be kept to a minimum. There are further aspects of citations that should be considered. If appropriate, has the language of the cited work been given? If secondary sources have been utilized, have the original sources been noted? Are journal titles spelled out? If abbreviated, have standard abbreviations been employed? User-friendly bibliographies will include a key to any abbreviations used.

Annotations greatly enhance the usefulness of a bibliography. These can be of three types: 1) informative, which show the reason titles have been included; 2) abstracts, which provide enough of the contents to enable users to decide whether they want to read the original; or 3) evaluative, which are critical appraisals written by individuals knowledgeable in the field. ${ }^{3}$ Annotations allow users of the bibliography to be more discriminating in regard to the value of particular titles for their specific needs. Though they take a great deal more work on the part of the author, annotations also demonstrate to the user that the author really has viewed each item included and possesses true familiarity with the subject area.

\section{Good indexes are very important}

Potential bibliography authors should give due thought to the access points that will be utilized in their work. Will there be a table of contents? What type(s) of indices will be included, e.g., author, title, subject, keyword, geographical, and/or chronological? How will the body of the bibliography itself be arranged? Alphabetical arrangement by author is the most widely used. Accession number, time period, and subject are other common methods, although these arrangements can all be problematic, for they do not easily lend themselves to a quick and natural understanding of the primary organization of the bibliography. Sidney Berger writes, "The arrangement of a bibliography should be immediately discernible from a glance at any two-page spread."

A very common shortcoming of many bibliographies is to include subject or keyword indices with categories that are much too broad. If subject or keyword indices are included, the bibliographer should create detailed, specific headings in order to avoid user frustration from being forced to page back and forth between large numbers of index references and their corresponding citations. Breaking down broad categories into narrower, more focused groups facilitates user satisfaction. Using narrower subject categories will often entail placing each citation in more than one index category. Indices which refer users to page numbers are much less practical than those which cite entries by means of individual entry numbers.

\section{Format makes a difference}

Finally, authors (and publishers) should be aware of the impact that the presentation and format of the published work can have on its readers. Is the typeface readable? Stanley Morison writes that, ". . . any disposition of printing material which, whatever the intention, has the effect of coming between author and reader is wrong." ${ }^{5}$ Have adequate margins been provided for photocopying? What about white space for annotating by the user? (Many libraries annotate citations with the call numbers of those items held in their collections.) Is the paper of superior quality? Has preservation (Bibliographies cont. on page 497) 


\section{Since $1879 \ldots$}

\section{Books}

Periodicals

Technology

Service

The BLACKWELL Companies

B. H. Blackwell

Tradition

Reliability

\section{Blackwell North America}

Blackwell Periodicals

Readmore

Readmore Academic Services 
initions and to incorporate them into your final document.

6) If your local needs dictate terms and conditions different from the standard license agreement, explain your situation clearly and succinctly. Be prepared to accommodate on some provisions and to seek changes in other areas-in other words, ask for what you believe you want, but realize you may not get everything.

7) Lay out for the vendor any local requirements that you may have for the purchase of an electronic product. Examples include sole-source statements, the number of agreement copies required, and the amount of time they can expect the process to take.

8) Once the product is installed, be prepared to monitor your usage of it to be sure you are in compliance with your license agreement. If your situation changes, promptly contact the vendor to accommodate this change.

Throughout ownership or lease of an electronic product patience, flexibility, and understanding are necessary. Vendors are not intimately familiar with the multitude of organizational structures used by library systems or colleges and universities. The license agreement represents a formal, legal commitment between the library and the vendor. It should be a source of imutual understanding for the operation of an electronic product.

\section{(Bibliographies cont. from page 472)}

paper been employed? Does the work have good-quality binding that will withstand heavy usage? Though these observations may appear obvious, the Oberly Committee has encountered nominations in its biannual deliberations which faltered on one or more of these points.

\section{Conclusion}

Though written more than sixty years ago, Arundell Esdaile's seven commandments to bibliographers still have validity for those considering such a project:

1. Be proud, and think highly of your calling

2. Be humble, and do not despise details.

3. Be accurate, in small things as in great.

4. Be brief.

5. Be clear

6. Take nothing on trust (uithont necessity, and not even then without saying so); there have been many bad bibliographers, and it is buman to err.

7. Never guess; you are sure to be found out, and then you will be written down as one of the bad bibliographers, than which there is no more terrible fate. ${ }^{6}$

An outstanding bibliography makes a significant contribution to the field of knowledge. It contains introductory material detailing the objective, scope, content, audience, and primary organization of the work as well as identifying the format of the citations. The bibliography should provide in-depth and accurate coverage of the selected subject area. Citations should be as complete as possible, and they should be verified before publishing. If possible, annotations or abstracts should be included. Multiple access points provide greater utility, but subject or keyword categories that are too broad should be avoided. An attempt should be made to maintain a pleasing typeface and adequate margins. Superior quality paper should always be employed and thought should be given to sturdy binding. Following these general guidelines will produce an outstanding bibliography that may win awards.

\section{Notes}

1. Roy Stokes, The Function of Bibliography (London: Andre Deutsch, 1969), p. 128.

2. D. W. Krummel, Bibliographies: Their Aims and Metbods (London: Mansell Publishing, 1984), p. 101.

3. Bibliography Committee, Reference and Adult Services Division, American Library Association, "Guidelines for the Preparation of a Bibliography," $R Q, 22$ (Fall 1982): 31-32.

4. Sidney E. Berger, "The Design of Bibliographies," AB Bookman's Weekly 86 (November 19, 1990): 1993-2000.

5. Stanley Morison, First Principles of Typography, 2nd ed. (London: Cambridge University Press, 1967), p. 5.

6. Arundell Esdaile, A Student's Manual of Bibliography (New York: Charles Scribner's Sons, 1931), p. 31.

\section{References}

Besterman, Theodore. $A$ World Bibliography of Bibliographies. 4th ed. Lausanne, Switzerland: Societas Bibliographica, 1965.

Toomey, Alice F. A World Bibliography of Bibliographies 1964-1974. Totowa, N.J.: Rowman and Littlefield, 1977. 